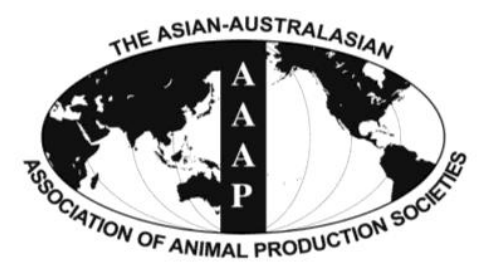

Asian-Aust. J. Anim. Sci.

Vol. 26, No. 3 : 394-400 March 2013

http://dx.doi.org/10.5713/ajas.2012.12430

www.ajas.info

pISSN 1011-2367 elSSN 1976-5517

\title{
Dietary Alpha Lipoic Acid Improves Body Composition, Meat Quality and Decreases Collagen Content in Muscle of Broiler Chickens
}

\author{
H. K. El-Senousey ${ }^{1,2}$, A. M. Fouad ${ }^{1,2}$, J. H. Yao ${ }^{1}$, Z. G. Zhang ${ }^{3}$ and Q. W. Shen ${ }^{1, *}$ \\ ${ }^{1}$ College of Animal Science and Technology, Northwest A \& F University, Yangling, Shaanxi, 712100, China
}

\begin{abstract}
A total of 192 broiler chicks were used to evaluate the influence of dietary $\alpha$-lipoic acid (ALA) on growth performance, carcass characteristics and meat quality of broiler chickens with the purpose of developing a strategy to prevent the occurrence of pale, soft, and exudative (PSE) meat and to improve the meat quality of broilers. At $22 \mathrm{~d}$ of age, birds were allocated to 4 ALA treatments (0, 400, 800, and $1200 \mathrm{ppm}$ ). The results showed that dietary ALA significantly decreased average feed intake (AFI), average daily gain (ADG), final live body weight $(\mathrm{BW})$ and carcass weight $(\mathrm{p}<0.05)$, while no difference in feed conversion ratio (FCR) was detected among chickens fed with and without ALA. Abdominal fat weight significantly decreased $(\mathrm{p}<0.05)$ for broilers fed 800 and $1200 \mathrm{ppm}$ ALA. However when calculated as the percentage of carcass weight there was no significant difference between control and ALA treatments. Meat quality measurements showed that dietary ALA regulated postmortem glycolysis and improved meat quality as evidenced by increased muscle $\mathrm{pH}$ and decreased drip loss of meat $(\mathrm{p}<0.05)$. Although ALA did not change the tenderness of meat as indicated by meat shear force, dietary ALA decreased collagen content and mRNA expression of COL3A1 gene ( $\mathrm{p}<0.05)$. In conclusion, the results indicate that dietary ALA may contribute to the improvement of meat quality in broilers. (Key Words: Broiler Chickens, $\alpha$-Lipoic Acid, PSE Meat, COL3A1 Gene)
\end{abstract}

\section{INTRODUCTION}

Excessive fat deposition within the body and the occurrence of pale, soft and exudative (PSE) meat are two major problems with poultry production (Zerehdaran et al., 2004; Barbut, 2009). The former is not only harmful for human health, but also a waste of feed when excessive feed intake is used for fat accumulation rather than muscle growth and development. Due to its inferior quality, like unfavorable color, low water holding capacity (WHC), tough texture after cooking and so on, PSE meat is not preferred by consumers (Barbut, 2009). According to reports, the incidence of PSE meat in chickens ranged from 0 to $28 \%$ in Canada (Barbut, 1997), from 37 to $47 \%$ in USA (Woelfel et al., 2002), and averaged at about $20 \%$ in England (Wilkins et al., 2000). Thus, the high incidence of PSE causes a huge economic loss to the poultry slaughter

\footnotetext{
* Corresponding Author: Qingwu W. Shen. Tel: +86-29-87092102, Fax: +86-29-87092164, E-mail: yaoyao3153@yahoo.com.cn

${ }^{2}$ Department of Animal Production, Faculty of Agriculture, Cairo University, Giza 12613, Egypt.

${ }^{3}$ College of food and bioengineering, Shandong Polytechnic University, University Road, Jinan, Shandong, China.

Submitted Aug. 7, 2012; Accepted Oct. 17, 2012; Revised Dec. 12, 2012
}

and meat processing industry (Woelfel et al., 2002). It is imperative to develop some strategies to control excessive body fat accumulation in chickens and the occurrence of PSE meat for both human health and economic aspects.

Alpha lipoic acid (ALA) is a naturally occurring shortchain fatty acid with a powerful antioxidant capacity, which widely exists in foods (Packer et al., 1995). In addition to its antioxidant property and free radical scavenging ability (Packer et al., 1995; Bilska and Wlodek, 2005), a body of literature has reported that ALA increases glucose uptake in skeletal muscle, reduces blood glucose level (Estrada et al., 1996; Jacob et al., 1996b; Streeper et al., 1997; Eason et al., 2002), and increases insulin sensitivity in individuals with type 2 diabetes (Jacob et al., 1995; Jacob 1996a; Jacob et al., 1999; Evans and Goldfine, 2000). ALA has also been shown to inhibit adipocyte differentiation (Cho et al., 2003) and induce body weight loss in obese subjects (Koh et al., 2011). In addition, our previous study on mice showed that dietary ALA inhibited postmortem glycolysis and increased $\mathrm{pH}$ values of muscle (Shen et al., 2005), indicating that dietary ALA might be used to prevent the occurrence of PSE meat, which has not been tested on poultry. Thereby dietary ALA could potentially improve meat quality in broilers. However, the studies regarding the effect of dietary 
ALA on meat quality of broilers is limited.

Thus, the purpose of this study was to re-evaluate the effects of dietary ALA on growth performance, body composition and meat quality in broiler chickens under the consumption of high doses of ALA diet as a means of improving the quality of broiler meat.

\section{MATERIALS AND METHODS}

\section{Birds, diets and experiment design}

All of the experiment was carried out under the approved protocols of the Animal Care Committee of the Northwest Agriculture and Forestry University (Yangling, China). A total of 192 one-d-old mixed-sex Arbor Acres broiler chicks were obtained from a local hatchery (Baoji da Cheng Qing ye poultry Co., Ltd, Shaanxi, China). All birds were fed the same commercial starter diet (1 to $21 \mathrm{~d}$ ) containing 21\% CP and 3,000 kcal of ME/kg (Hua Qin Co., Ltd., Shaanxi, China). Thereafter, a finisher diet (22 to $42 \mathrm{~d}$ ) with $19.1 \% \mathrm{CP}$ and 3,037 kcal/kg ME was fed. At $22 \mathrm{~d}$ the broilers were weighed and randomly allotted to four dietary treatment groups with 8 replicates of 6 birds per replicate cage for each treatment. Control birds were fed the basal diet without ALA, while birds with ALA were fed the basal diet to which ALA (400, 800, and 1,200 ppm) was added. $\alpha$-lipoic acid was purchased from a pharmaceutical company (Shaanxi Xintai Pharmaceutical Co., Ltd., China). The basal diets (Table 1) were formulated to recommendations of the NRC (1994).

Feed and water were freely available to all birds. Throughout the experiment, the temperature of the room was approximately $35^{\circ} \mathrm{C}$ during the first week and then decreased gradually to a constant temperature of $25^{\circ} \mathrm{C}$, which was held until the end of the experiment. A 24-h lighting regimen was provided, and birds were vaccinated against Newcastle disease and infectious bursal disease according to commercial recommendations. Average feed intake (AFI), average daily gain (ADG) and feed conversion ratio (FCR) were calculated weekly.

\section{Sample collection}

On d 42 of the experiment, 2 broilers from each cage were selected according to the average $\mathrm{BW}$ within the cage after a 12-h fast, weighed individually, slaughtered and then were immediately bled. Feathers were picked with the use of commercial defeathering equipment. After removing heads and feet, carcasses were eviscerated and weighted. Dressing percentage was calculated by dividing the carcass weight by live BW. The left side of the breast and leg muscles were removed after deboning and weighed. Abdominal fat, composed of fat tissues surrounding the proventriculus and gizzard lying against the inside abdominal wall and around the cloaca, was collected and
Table 1. Basal diet composition and chemical analysis

\begin{tabular}{lc}
\hline Ingredient & Finisher diet $(22-42 \mathrm{~d})$ \\
\hline Maize & 63.21 \\
Soybean meal 43\% & 29.00 \\
Soy oil & 2.70 \\
Fish meal & 2.00 \\
Limestone & 1.30 \\
Dicalcium phosphate & 1.20 \\
Salt & 0.30 \\
Methionine & 0.15 \\
Trace mineral mix ${ }^{1}$ & 0.10 \\
Vitamin premix ${ }^{2}$ & 0.04 \\
Nutrient and energy level (calculated) & \\
CP (\%) & 19.1 \\
ME (MJ/kg) & 12.71 \\
Lysine (\%) & 0.98 \\
Methionine (\%) & 0.47 \\
Methionine+cystine (\%) & 0.81 \\
Calcium (\%) & 0.86 \\
Total phosphorus (\%) & 0.57 \\
Available phosphorus (\%) & 0.37
\end{tabular}

${ }^{1}$ Trace mineral mix supplied per kg of diet: manganese, $75 \mathrm{mg}$; zinc, 69 $\mathrm{mg}$; copper, $7 \mathrm{mg}$; iodine, $0.4 \mathrm{mg}$; iron, $4 \mathrm{mg}$; and selenium, $0.2 \mathrm{mg}$.

2 Vitamin premix supplied per $\mathrm{kg}$ of diet: vitamin A, 12,000 IU; cholecalciferol, 4,000 IU; vitamin E (DL- $\alpha$-tocopheryl acetate), $30 \mathrm{IU}$; vitamin $\mathrm{K}_{3}, 3 \mathrm{mg}$; thiamine, $2.2 \mathrm{mg}$; riboflavin, $10 \mathrm{mg}$; pyridoxine, $4 \mathrm{mg}$; vitamin B12, $0.02 \mathrm{mg}$; pantothenic acid, $7 \mathrm{mg}$; nicotinic acid, $37.0 \mathrm{mg}$; folic acid, $0.30 \mathrm{mg}$; biotin, $0.20 \mathrm{mg}$; choline chloride, $400 \mathrm{mg}$.

weighed to determine the effects of ALA on body fat deposition as described by Ain Baziz et al. (1996). The percentage of abdominal fat was calculated by dividing the weight of abdominal fat by carcass weight; the percentage of breast and leg muscle was calculated by dividing the breast and leg weight by carcass weight.

Breast muscle from the right sides of each carcass was used to determine muscle $\mathrm{pH}$ values while the left sides was used to measure the drip loss and shear force. Fillets from the right sides were immediately frozen in liquid nitrogen and stored at $-80^{\circ} \mathrm{C}$ until analyses.

\section{Measurements of meat quality}

Muscle $p H$ : Breast muscle $\mathrm{pH}$ was measured in the upper one-third of the pectoral major muscle from the right side with pH meter PB-10 (Sartorius Scientific Instruments Co., Ltd., Beijing, China). Muscle samples of 8 birds were used to measure the $\mathrm{pH} 0 \mathrm{~h}$ postmortem. This measurement was done immediately after chicken was slaughtered without feather removal and evisceration. Muscle samples from 8 additional birds were collected to determine the $\mathrm{pH}$ value at different time points $(0.5,2$ and $24 \mathrm{~h}$ postmortem) as described by Jeacocke (1977).

\section{Drip loss measurements}

Drip loss was measured as described by Remignon et al. 
(1996). The breast muscles were excised, weighed and then placed in a polyethylene bag and stored at $4^{\circ} \mathrm{C}$. The muscles were removed from the bag after $24 \mathrm{~h}$, wiped and weighed to evaluate the drip loss, which was expressed as a percentage of the initial muscle weight.

\section{Shear force measurements}

Tenderness was measured using a Digital Meat Tenderness Meter (Model C-LM 3B, Northeast Agricultural University, China). Breast meat samples (1.5 $\mathrm{cm} \times 3.0$ $\mathrm{cm} \times 0.5 \mathrm{~cm}$ ) were heated in plastic bags in a water bath at $80^{\circ} \mathrm{C}$ for $10 \mathrm{~min}$ and then cooled to room temperature. Three cores of $1.27 \mathrm{~cm}$ in diameter were removed from each cooked fillet for shear force determination as described by Molette et al. (2003). Maximum force measured was expressed as kilogram force $(\mathrm{kg} \cdot \mathrm{f} / \mathrm{g}$ of meat).

\section{Glycogen content determination}

The muscles glycogen content were determined with commercial kits (Nanjing Jiancheng Bioengineering Institute, Nanjing City, China), which have been used previously in broiler chickens (Lin et al., 2007).

\section{Collagen content measurement}

The determination of hydroxyproline content was used to measure the muscles collagen content. The assay was performed according to the instruction of the hydroxyproline test kit from a biochemical company (Nanjing Jiancheng Bioengineering Institute, Nanjing City, China). Skeletal muscle collagen contains $13.3 \%$ hydroxyproline and total collagen content was calculated by multiplying the hydroxyproline content by 7.25 (Goll et al., 1963; Cross et al., 1973). The collagen content was expressed as milligrams of collagen per gram of muscle.

\section{COL3A1 mRNA measurement by RT-PCR}

Total RNA was extracted from the breast muscle with the RNAiso Plus (TakaRa Biotechnology Co. Ltd., Dalian, China) according to the manufacturer's protocol. The concentration and integrity of extracted total RNA were determined by the absorbance at $\mathrm{A}_{260}$ and $\mathrm{A}_{280}$ and by agarose gel electrophoresis, respectively. cDNA was then synthesized. Briefly, $1 \mu \mathrm{g}$ of RNA was reacted with $4 \mu \mathrm{l}$ of
$5 \times$ PrimeScript Buffer, $1 \mu \mathrm{l}$ of PrimeScript RT Enzyme Mix I, $1 \mu \mathrm{l}$ of Oligo dT primer, $1 \mu \mathrm{l}$ of Random 6 mers and RNase-free water (TaKaRa, Biotechnology Co. Ltd., Dalian, China) to a final volume of $20 \mu \mathrm{l}$. After incubation $\left(42^{\circ} \mathrm{C}\right.$, $30 \mathrm{~min})$, the mixture was heated to stop reaction. Quantitative real time PCR (qRT-PCR) was performed in a volume of $20 \mu$ containing $10 \mu \mathrm{l}$ of SYBR Premix Ex Taq (Takara Biotechnology Co. Ltd), $0.8 \mu \mathrm{l}$ of forward primer, $0.8 \mu \mathrm{l}$ of reverse primer, $2.0 \mu \mathrm{l}$ of cDNA, and $6.4 \mu \mathrm{l}$ free nuclease water. $\beta$-actin was used as an internal control. The primer sequences and their respective GenBank accession numbers are listed in Table 6.

The PCR reaction was conducted on a Bio-Rad iQTM5 (Optical module, USA) and the protocol used as follows: $94^{\circ} \mathrm{C}$ for $3 \mathrm{~min}, 40$ cycles of $10 \mathrm{sec}$ at $94^{\circ} \mathrm{C}, 30 \mathrm{sec}$ at $60^{\circ} \mathrm{C}$. Fluorescence measurements were collected at every cycle during the extension step $\left(60^{\circ} \mathrm{C}\right)$. Col3A1 gene expression was calculated by using the $2^{-\triangle \Delta C T}$ method according to Livak and Schmittgen (2001).

\section{Statistical analyses}

Data were analyzed by one-way ANOVA using the GLM procedure of SAS Institute (2001). Data for muscle $\mathrm{pH}$ were analyzed using the PROC MIXED procedure for repeated measures model that included time and treatment $\times$ time interactions. The significance of differences among treatments at each time point was tested using LSMEANS with the PDIFF option. Significance was declared at $\mathrm{p} \leq 0.05$.

\section{RESULTS AND DISCUSSION}

\section{Growth performance and carcass characteristics}

In the present study, dietary ALA was observed to decrease ADG $(\mathrm{p}=0.0004)$ and BW $(\mathrm{p}=0.0004)$ in broiler chickens during the last three weeks. Broiler chickens fed diets containing 0, 400, 800 and 1,200 ppm of ALA had ADG of 75.50, 70.63, 65.50 and $65.75 \mathrm{~g}$, respectively, and final $\mathrm{BW}$ of $2,512.9,2,399,2,290.8$ and 2,316.5 g, respectively. The reduction in ADG and BW increased with the increase of ALA concentration (Table 2). This is in agreement with a previous study which showed that dietary ALA supplementation decreased weight gain (Shen et al.,

Table 2. Effects of dietary ALA on growth performance of broilers

\begin{tabular}{|c|c|c|c|c|c|c|}
\hline \multirow[b]{2}{*}{ Item $^{1}$} & \multicolumn{4}{|c|}{ Dietary ALA } & \multirow{2}{*}{ Pooled SEM } & \multirow{2}{*}{ p-value } \\
\hline & Control & $400 \mathrm{ppm}$ & $800 \mathrm{ppm}$ & $1,200 \mathrm{ppm}$ & & \\
\hline$\overline{\mathrm{ADG}(\mathrm{g})}$ & $75.50^{\mathrm{a}}$ & $70.63^{b}$ & $65.50^{c}$ & $65.75^{c}$ & 1.07 & 0.0004 \\
\hline AFI (g) & $155.13^{\mathrm{a}}$ & $151.13^{\mathrm{a}}$ & $144.13^{\mathrm{b}}$ & $142.38^{b}$ & 1.28 & 0.0001 \\
\hline FCR (g:g) & $2.06^{\mathrm{a}}$ & $2.15^{\mathrm{a}}$ & $2.21^{\mathrm{a}}$ & $2.17^{\mathrm{a}}$ & 0.028 & 0.279 \\
\hline Final BW (g) & $2,512.9^{\mathrm{a}}$ & $2,399.0^{\mathrm{b}}$ & $2,290.8^{c}$ & $2,316.5^{\mathrm{bc}}$ & 22.56 & 0.0004 \\
\hline
\end{tabular}

$\overline{a, b, c}$ Means within a row that do not have a common superscript letter differ $(\mathrm{p}<0.05)$.

${ }^{1} \mathrm{ADG}=$ Average daily gain; $\mathrm{AFI}=$ Average feed intake FCR $=$ Feed conversion ratio, $\mathrm{BW}=$ Body weight. 
2005; Zhang et al., 2009). Nevertheless, in the current experiment, no significant difference was observed among treatments for feed conversion ratio (FCR). Birds consumed significantly less feed when diets were supplemented with 800 and 1200 ppm ALA relative to control birds (Table 2).

Consistent with the ADG and BW, dietary ALA significantly decreased $(p<0.01)$ the carcass weight of broiler chickens at 800 and 1,200 ppm with no effect on dressing percentage (Table 3). Since meat yield, as well as meat quality, is also important for meat animal production and agriculture efficiency, we then estimated the influence of dietary ALA on chicken muscle growth and meat yield. Both breast and leg muscle weight showed that, although numerically lower muscle weight was detected in chickens fed ALA, ALA did not significantly inhibit chicken muscle growth and did not decrease broilers muscle mass, indicating that dietary ALA did not influence meat yield in broilers (Table 3). As expected, dietary ALA did inhibit animal body fat deposition as evidenced by the reduction in abdominal fat weight $(\mathrm{p}=0.0003)$ observed in this study (Table 3). However when calculated as the percentage of carcass weight, there was no significant difference in abdominal fat weight between control and ALA treatments.

The major purpose of this study was to evaluate the influence of dietary ALA on broiler chickens growth performance, carcass characteristics and meat quality with the purpose to develop a strategy to improve meat quality without sacrificing meat yield. The data obtained showed that dietary ALA decreased chicken ADG, final BW at slaughter and carcass weight. This reduction in ADG, BW and carcass weight did not result from inhibited muscle growth and deceased muscle mass as both breast and leg muscle weight was not affected by dietary ALA supplementation. As expected, ALA inhibition of body fat accumulation seemed to account for the reduced BW and carcass weight as dietary ALA significantly reduced abdominal fat weight in grams, but not as a percentage of carcass weight (Table 3). On the contrary, our previous study showed that ALA decreased percentage weight of abdominal fat in mice (Shen et al., 2005). This was probably due to the much higher doses of ALA (0.5 and $1.0 \%$ ) used in that study, which inhibited adipocyte differentiation (Cho et al., 2003) and promoted fatty acid $\beta$-oxidation (Shen et al., 2007).

The decreased ADG, BW, carcass weight and thus body fat weight could also be contributing to a decreased AFI, as a response to the inhibition of AMPK activity in the hypothalamus and thus ALA reducing the appetite of animals (Kim et al., 2004), which is in agreement with the results of Shen et al. (2005) in mice and Zhang et al. (2009) in broilers. In contrast, Chen et al. (2011) concluded that dietary ALA at low concentrations $(0,100,200,300 \mathrm{mg} / \mathrm{kg})$ had no significant effect on ADFI in broilers.

In previous studies, it was also reported that ALA (0.5 and $1.0 \%$ ) inhibited muscle growth and reduced muscle mass in mice (Shen et al., 2005) probably by ALA activation of AMPK in skeletal muscle cells (Shen et al., 2007), which then inhibits protein synthesis and muscle growth (Lantier et al., 2010). We just observed mild, but not significant reduction in both breast and leg muscle weight of chickens fed 800 and 1,200 ppm of ALA in the present study. These differences could also be explained by the much lower ALA doses used in our study. In fact, similar observations had been reported by others (Hamano et al., 1999; Hamano et al., 2002) which showed that 0 to 100 $\mathrm{mg} / \mathrm{kg}$ of ALA did not inhibit muscle growth, but reduced body fat deposition.

\section{Meat quality}

PSE meat is one of the major problems facing the poultry industry (Barbut, 2009). PSE meat is characterized by a high acidification rate in muscle shortly following animal death (Briskey, 1964; Offer, 1991). It has been well established that too rapid and/or excessive postmortem $\mathrm{pH}$ decline in muscle, while the muscle temperature is still high, causing denaturation of proteins (Sayre et al., 1963; Briskey 1964; Bendall and Swatland, 1988; Lee and Choi, 1999), is the direct cause of the inferior attributes of PSE meat, such

Table 3. Effects of dietary ALA on carcass characteristics of broilers

\begin{tabular}{|c|c|c|c|c|c|c|}
\hline \multirow[b]{2}{*}{ Traits } & \multicolumn{4}{|c|}{ Dietary ALA } & \multirow{2}{*}{ Pooled SEM } & \multirow{2}{*}{$\mathrm{p}$-value } \\
\hline & Control & $400 \mathrm{ppm}$ & $800 \mathrm{ppm}$ & $1,200 \mathrm{ppm}$ & & \\
\hline Carcass weight (g) & $1,898.4^{\mathrm{a}}$ & $1,808.3^{\mathrm{a}}$ & $1,664.4^{\mathrm{b}}$ & $1,588.1^{\mathrm{b}}$ & 29.0 & 0.0002 \\
\hline Dressing percentage & 74.0 & 70.4 & 70.6 & 72.6 & 0.89 & 0.435 \\
\hline Breast muscle weight (g) & 248.1 & 230.1 & 225.4 & 224.8 & 5.6 & 0.47 \\
\hline Breast muscle $(\%)^{1}$ & 13.3 & 12.7 & 13.5 & 14.2 & 0.27 & 0.33 \\
\hline Leg muscle weight $(\mathrm{g})$ & 180.9 & 178.9 & 164.8 & 156.6 & 5.1 & 0.32 \\
\hline Leg muscle $(\%)^{1}$ & 9.7 & 9.9 & 9.9 & 9.9 & 0.20 & 0.98 \\
\hline Abdominal fat weight (g) & $29.1^{\mathrm{a}}$ & $30.3^{\mathrm{a}}$ & $24.5^{\mathrm{b}}$ & $24.0^{\mathrm{b}}$ & 0.69 & 0.0003 \\
\hline Abdominal fat $(\%)^{1}$ & 1.6 & 1.7 & 1.5 & 1.5 & 0.04 & 0.18 \\
\hline
\end{tabular}

${ }^{\mathrm{a}, \mathrm{b}}$ Means within a row that have different superscript differ $(\mathrm{p}<0.05)$.

${ }^{1}$ Breast muscle, leg muscle and abdominal fat are expressed as percentages of carcass weight. 
as low WHC, watery appearance, and high drip loss.

With the purpose to develop a strategy to prevent PSE meat, we evaluated the effect of dietary ALA supplementation on meat quality of broiler chickens (Table 4). As expected, the data obtained showed that ALA inhibited chicken muscles glycolysis early postmortem as evidenced by increased $\mathrm{pH}$. There was a significant effect of dietary ALA $(p<0.05)$, postmortem time $(p<0.05)$ and dietary ALA $\times$ time interaction $(\mathrm{p}=0.002)$ on postmortem muscle $\mathrm{pH}$. Feeding diets supplemented with ALA to chickens effectively retarded early postmortem $\mathrm{pH}$ decline, which is in agreement with literature which showed that ALA inhibited postmortem glycolysis and increased $\mathrm{pH}$ in muscle of mice (Shen et al., 2005).

Recent advances highlighted that the final $\mathrm{pH}$ of the breast meat is negatively related to the muscle glycogen stores (Berri et al., 2005; Duclos et al., 2007). Biomedical studies show that ALA increases muscle glucose uptake (Eason et al., 2002). Our previous study also showed that dietary ALA changed mouse longissimus dorsi (LD) muscle glycolytic potential (Shen et al., 2005). To understand the potential mechanism whereby ALA changes muscle postmortem glycolysis and $\mathrm{pH}$, we measured the glycogen content in muscles. Our data showed that, glycogen content in muscle of chickens supplemented with ALA showed a tendency to decrease among treatments $(p=0.058)$. This supports the previous hypothesis that the effects of ALA on animal growth, body composition and muscle postmortem glycolysis are concentration dependent. Zhang et al. (2009) also reported that ALA increased $\mathrm{pH}$ after $24 \mathrm{~h}$ in both breast and thigh muscles of broiler chickens at high concentration (900 ppm), but not lower concentrations ( $\leq 600 \mathrm{ppm}$ ). However, they did not measure the muscle $\mathrm{pH}$ early postmortem and glycogen content in muscles.

WHC of meat is one of the most important aspects of meat quality for both consumer and processor. A low WHC in muscles can increase the liquid outflow, loss of soluble nutrients and flavor. Thus, the muscle becomes dry, hard and tasteless. WHC of broiler meat was evaluated in this study by measuring drip loss. Data in Table 5 showed that dietary ALA significantly decreased drip loss of meat in a dose-dependent manner $(\mathrm{p}=0.008)$, which decreased from $1.75 \%$ in control to $0.95 \%$ when 1200 ppm of ALA was
Table 4. Effects of dietary ALA on postmortem muscle $\mathrm{pH}^{1}$

\begin{tabular}{lccccc}
\hline & \multicolumn{4}{c}{ Time postmortem $(\mathrm{h})$} & Pooled \\
\cline { 2 - 5 } Dietary ALA & 0 & 0.5 & 2 & 24 & SEM \\
Control & $5.95^{\mathrm{a}}$ & $5.78^{\mathrm{d}}$ & $5.46^{\mathrm{e}}$ & $5.16^{\mathrm{f}}$ & 0.04 \\
$400 \mathrm{ppm}$ & $5.95^{\mathrm{ab}}$ & $5.80^{\text {cd }}$ & $5.78^{\text {cd }}$ & $5.21^{\mathrm{f}}$ & 0.04 \\
$800 \mathrm{ppm}$ & $5.96^{\mathrm{a}}$ & $5.83^{\text {bcd }}$ & $5.79^{\text {cd }}$ & $5.24^{\mathrm{f}}$ & 0.04 \\
$1,200 \mathrm{ppm}$ & $5.90^{\text {abc }}$ & $5.83^{\text {cd }}$ & $5.73^{\mathrm{d}}$ & $5.18^{\mathrm{f}}$ & 0.04 \\
\hline
\end{tabular}

${ }^{1}$ Least squares means that do not have a common superscript letter (a-f) differ $(\mathrm{p}<0.05)$. The effects of dietary ALA, time and dietary ALA $\times$ time interaction are significant $(\mathrm{p}<0.01)$.

added to the diet. These data indicate that dietary ALA improves the quality of broilers meat, which is supported by the study of Zhang et al. (2009) showing that ALA also improved broilers meat color.

Shear force is indicative of meat tenderness, which has been noted as the most important factor in consumer perception of palatability or quality of meat products (Savell et al., 1989). ALA had no significant effects on shear force in the present study ( $p>0.05$, Table 5). Others reported that dietary ALA decreased $(\mathrm{p}<0.01)$ WarnerBratzler shear force values (Schmidt et al., 2005; Zhang et al., 2009). Since shear force is influenced by multiple factors, we are not sure of the reasons for the inconsistent data among studies

Although no difference in shear force was detected among treatments, ALA decreased collagen content and mRNA expression of the COL3A1 gene in muscle of broiler chickens supplemented with ALA at 800 ppm or higher $(p<0.05)$ (Table 5 and Figure 1). Since collagen is the major component of the intramuscular connective tissue and plays a key role in determining meat toughness (Liu et al., 1996; Torrescano et al., 2003), the action of ALA on collagen expression in muscle suggests that dietary ALA could potentially be used to increase meat tenderness in animal production although this is not supported by our data here, but it is supported by others (Zhang et al., 2009). To our knowledge, this is the first report showing that ALA regulates collagen expression in muscles, which is beneficial for meat quality improvement in animal production.

In conclusion, this study demonstrated that dietary ALA inhibited body fat deposition and mRNA expression of the

Table 5. Effects of dietary ALA on the meat quality of broilers

\begin{tabular}{|c|c|c|c|c|c|c|}
\hline \multirow[b]{2}{*}{ Traits } & \multicolumn{4}{|c|}{ Dietary ALA } & \multirow{2}{*}{ Pooled SEM } & \multirow{2}{*}{$\mathrm{p}$-value } \\
\hline & Control & $400 \mathrm{ppm}$ & $800 \mathrm{ppm}$ & $1,200 \mathrm{ppm}$ & & \\
\hline Glycogen $(\mathrm{mg} / \mathrm{g})$ & 2.36 & 2.34 & 2.32 & 1.89 & 0.07 & 0.058 \\
\hline SHV (kgf/g) & 1.82 & 1.79 & 1.75 & 1.53 & 0.07 & 0.440 \\
\hline Drip loss (g) & $4.46^{\mathrm{a}}$ & $2.84^{\mathrm{b}}$ & $2.51^{\mathrm{b}}$ & $2.14^{\mathrm{b}}$ & 0.25 & 0.002 \\
\hline Drip loss (\%) & $1.75^{\mathrm{a}}$ & $1.27^{\mathrm{b}}$ & $1.10^{\mathrm{b}}$ & $0.95^{\mathrm{b}}$ & 0.09 & 0.008 \\
\hline Collagen (mg/g) & $3.75^{\mathrm{a}}$ & $3.31^{\mathrm{a}}$ & $2.69^{b}$ & $2.06^{\mathrm{c}}$ & 0.16 & 0.0003 \\
\hline
\end{tabular}

\footnotetext{
${ }_{\mathrm{a}, \mathrm{b}, \mathrm{c}}$ Means within a row that have different superscript differ $(\mathrm{p}<0.05)$.
} 


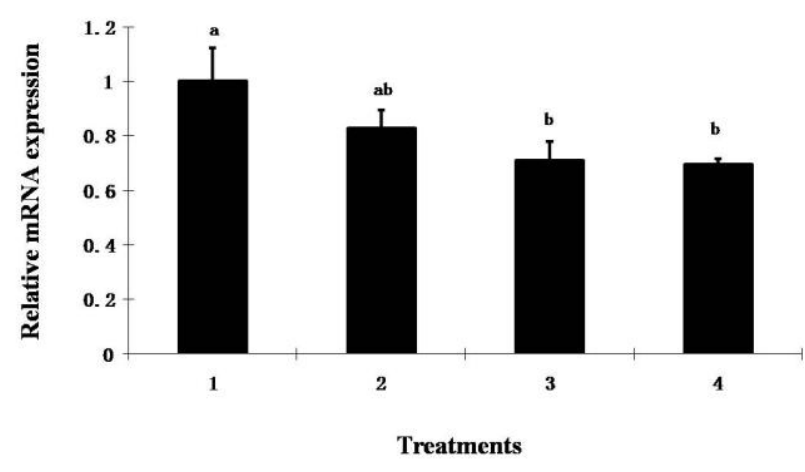

Figure 1. The effect of dietary ALA on Col3A1 mRNA expression in broiler chickens. Diets contained 0 ppm (control), 400 ppm (T1), 800 ppm (T2) and 1,200 ppm (T3) of ALA in diet. ${ }^{a-b}$ Bars with different superscripts are significantly different $(\mathrm{p}<0.05)$. Error bars show SEM.

Table 6. The forward and reverse primers for Col3A1 gene and $\beta$-actin

\begin{tabular}{lcc}
\hline Gene & Primer sequence $\left(5^{\prime} \rightarrow 3^{\prime}\right)$ & $\begin{array}{c}\text { Accession } \\
\text { number }\end{array}$ \\
\hline Col3A1 F-5'-CCGTGTTTCAACCCTCAGTT-3' & NM_205380.2 \\
R-5'-TAGGCTGTGGTGTTGTCTGC-3' & \\
$\beta$-actin & $\begin{array}{l}\text { F-5'-TGCGTGACATCAAGGAGAAG-3' } \\
\text { R-5'-TGCCAGGGTACATTGTGGTA-3' }\end{array}$ & L08165 \\
\hline
\end{tabular}

${ }^{1}$ Genbank accession number.

COL3A1gene in muscle, decreased muscle glycolysis early postmortem and improved the water holding capacity (WHC) of meat without sacrificing muscle mass and meat yield, suggesting that ALA could be used effectively to improve meat quality and to prevent PSE meat in poultry production. However, this study also suggests that dietary supplementation with high-dose ALA has negative effects on growth performance of broilers. Based on the data obtained in this study and reported in literature, we suggest that 400 to $800 \mathrm{ppm}$ of ALA is an appropriate dose for poultry production taking both meat quality and yield into account.

\section{ACKNOWLEDGEMENTS}

This work was supported by the initial funding from Northwest Agriculture and Forestry University (Z111021006). The authors want to acknowledge Professor. Arnold Saxton (Department of Animal Science, University of Tennessee) for his kind assistance in statistics.

\section{REFERENCES}

Ain Baziz, H., P. A. Geraert, J. C. Padilha and S. Guillaumin. 1996. Chronic heat exposure enhances fat deposition and modifies muscle and fat partition in broiler carcasses. Poult. Sci. 75:505-513.
Barbut, S. 1997. Problem of pale soft exudative meat in broiler chickens. Br. Poult. Sci. 38:355-358.

Barbut, S. 2009. Pale, soft, and exudative poultry meat-Reviewing ways to manage at the processing plant. Poult. Sci. 88:15061512.

Bendall, J. R. and H. J. Swatland. 1988. A review of the relationship of $\mathrm{pH}$ with physical aspects of pork quality. Meat Sci. 24:85-126.

Berri, C., M. Debut, V. Sante-Lhoutellier, C. Arnould, B. Boutten, N. Sellier, E. Baeza, N. Jehl, Y. Jego, M. J. Duclos and E. Le Bihan-Duval. 2005. Variations in chicken breast meat quality: implications of struggle and muscle glycogen content at death. Br. Poult. Sci. 46:572-579.

Bilska, A. and L.Wlodek. 2005. Lipoic acid - the drug of the future? Pharmacol. Rep. 57:570-577.

Briskey, E. J. 1964. Etiological status and associated studies of pale, soft, exudative porcine musculature. Adv. Food Res. 13:89-178

Chen, P., Q. G. Ma, C. Ji, J.Y. Zhang, L. H. Zhao, Y. Zhang and Y. Z. Jie. 2011. Dietary lipoic acid influences antioxidant capability and oxidative status of broilers. Int. J. Mol. Sci. 12:8476-8488.

Cho, K. J., H. E. Moon, H. Moini, L. Packer, D. Y. Yoon and A. S. Chung. 2003. Alpha-lipoic acid inhibits adipocyte differentiation by regulating pro-adipogenic transcription factors via mitogen-activated protein kinase pathways. J. Biol. Chem. 278:34823-34833.

Cross, H. R., J. L Carpenter and G. C. Smith. 1973. Effect of intramuscular collagen and elastin on bovine muscle tenderness. J. Food Sci. 38:998-1003.

Duclos, M. J., C. Berri and E. Le Bihan-Duval. 2007. Muscle growth and meat quality. J. Appl. Poult. Res. 16:107-112.

Eason, R. C., H. E. Archer, S. Akhtar and C. J. Bailey. 2002. Lipoic acid increases glucose uptake by skeletal muscles of obese-diabetic ob/ob mice. Diabetes Obes. Metab. 4:29-35.

Estrada, D. E., H. S. Ewart, T. Tsakiridis, A. Volchuk, T. Ramlal, H. Tritschler and A. Klip. 1996. Stimulation of glucose uptake by the natural coenzyme alpha-lipoic acid/thioctic acid: participation of elements of the insulin signaling pathway. Diabetes 45:1798-1804.

Evans, J. L. and I. D. Goldfine. 2000. Alpha-lipoic acid: a multifunctional antioxidant that improves insulin sensitivity in patients with type 2 diabetes. Diabetes Technol. Ther. 2:401413.

Goll, D. E., R. W. Bray and W. G. Hoerstra. 1963. Age associated changes in muscle composition. The isolation and properties of a collagenous residue from bovine muscle. J. Food Sci. 28:503-509

Hamano, Y., S. Sugawara, Y. Kamota and E. Nagai. 1999. Involvement of lipoic acid in plasma metabolites, hepatic oxygen consumption, and metabolic response to a beta-agonist in broiler chickens. Br. J. Nutr. 82:497-503.

Hamano, Y. 2002. Influence of lipoic acid on lipid metabolism and beta-adrenergic response to intravenous or oral administration of clenbuterol in broiler chickens. Reprod. Nutr. Dev .42:307316.

Jacob, S., E. J. Henriksen, A. L. Schiemann, I. Simon, D. E. Clancy, H. J. Tritschler, W. I. Jung, H. J. Augustin and G. J. Dietze. 1995. Enhancement of glucose disposal in patients 
with type 2 diabetes by alpha-lipoic acid. Arzneimittelforschung 45:872-874.

Jacob, S., E. J. Henriksen, H. J. Tritschler, H. J. Augustin and G. J. Dietze. 1996a. Improvement of insulin-stimulated glucosedisposal in type 2 diabetes after repeated parenteral administration of thioctic acid. Exp. Clin. Endocrinol. Diabetes 104:284-288

Jacob, S., P. Ruus, R. Hermann, H. J. Tritschler, E. Maerker, W. Renn, H. J. Augustin, G. J. Dietze and K. Rett. 1999. Oral administration of RAC-alpha-lipoic acid modulates insulin sensitivity in patients with type- 2 diabetes mellitus: a placebocontrolled pilot trial. Free Radic. Biol. 27:309-314.

Jacob, S., R. S. Streeper, D. L. Fogt, J. Y. Hokama, H. J. Tritschler, G. J. Dietze and E. J Henriksen. 1996b. The antioxidant alphalipoic acid enhances insulin-stimulated glucose metabolism in insulin-resistant rat skeletal muscle. Diabetes 45:1024-1029.

Jeacocke, R. E. 1977. Continuous measurements of the $\mathrm{pH}$ (hydrogen ion concentration) of beef muscle in intact beef carcasses. J. Food Technol. 12:375-386.

Kim, M. S., J. Y. Park, C. Namkoong, P. G. Jang, J. W. Ryu, H. S Song, J. Y. Yun, I. S. Namgoong, J. Ha, I. S. Park, I. K. Lee, B. Viollet, J. H. Youn, H. K. Lee and K. U. Lee. 2004. Antiobesity effects of alpha-lipoic acid mediated by suppression of hypothalamic AMP-activated protein kinase. Nat. Med. 10:727-733

Koh, E. H., W. J. Lee, S. A. Lee, E. H. Kim, E. H. Cho, E. Jeong, D.W. Kim, M. S. Kim, J.Y. Park, K. G. Park, H. J. Lee, I. K. Lee, S. Lim, H. C. Jang, K. H. Lee and K. U. Lee. 2011. Effects of alpha-lipoic acid on body weight in obese subjects. Am. J. Med. 124:85.e81-88.

Lantier, L., R. Mounier, J. Leclerc, M. Pende, M. Foretz and B. Viollet. 2010. Coordinated maintenance of muscle cell size control by AMP-activated protein kinase. FASEB J. 24:35553561.

Lee, Y. B and Y. I. Choi. 1999. PSE (pale, soft, exudative) pork: The causes and solutions - review. Asian-Aust. J. Anim. Sci. $12: 244-252$

Liu, A., T. Nishimura and K. Takahashi. 1996. Relationship between structural properties of intramuscular connective tissue and toughness of various chicken skeletal muscles. Meat Sci. 43:43-49.

Lin, H., S. J. Sui, H. C. Jiao, K. J. Jiang, J. P. Zhao and H. Dong. 2007. Effects of diet and stress mimicked by corticosterone administration on early postmortem muscle metabolism of broiler chickens. Poult. Sci. 86:545-554.

Livak, K. J. and T. D. Schmittgen. 2001. Analysis of relative gene expression data using real-time quantitative PCR and the 2(Delta Delta C(T)) Method. Methods 25:402-408.

Molette, C., H. Remignon and R. Babile. 2003. Effect of rate of $\mathrm{pH}$ fall on turkey breast meat quality. Br. Poult. Sci. 44:787788.

NRC. 1994. Nutrient Requirements of Poultry. National Academy Press, Washington, DC, USA.
Offer, G. 1991. Modelling of the formation of pale, soft and exudative meat: Effects of chilling regime and rate and extent of glycolysis. Meat Sci. 30:157-184.

Packer, L., E. H. Witt and H. J. Tritschler. 1995. alpha-Lipoic acid as a biological antioxidant. Free Radic. Biol. Med. 19:227-250.

Remignon, H., V. Desrosiers, G. Marche. 1996. Influence of increasing breast meat yield on muscle histology and meat quality in the chicken. Reprod. Nutr. Dev. 36:523-530.

SAS Institute. 2001. JMP IN Start Statistics, (Version 4.0.4. Edition 2.). SAS Inst. Inc., Cary, N.C. USA.

Savell, J. W., H. R. Cross, J. J. Francis, J. W. Wise, D. S. Hale, D. L. Wilkes and G. C. Smith. 1989. National consumer retail beef study: Interaction of beef trim level price and grade on consumer acceptance of beef steaks and roasts. Food Qual. 12:251-274.

Schmidt, T. B., K. C. Olson, PAS, D. L. Meyer, M. M. Brandt, G. K. Rentfrow, C. A. Stahl and E. P. Berg. 2005. Effects of lipoic acid supplementation on finishing steer growth performance, carcass merit, beef tenderness, and beef retail display properties. Prof. Anim. Scient. 21:480-485.

Sayre, R. N., E. J Briskey and W. G. Hoekstra. 1963. Effect of excitement, fasting and sucrose feeding on porcine muscle phosphorylase and postmortem glycolysis. J. Food Sci. 28:472-477.

Shen, Q. W., C. S. Jones, N. Kalchayanand, M. J. Zhu and M. Du. 2005. Effect of dietary $\alpha$-lipoic acid on growth, body composition, muscle $\mathrm{pH}$, and AMP-activated protein kinase phosphorylation in mice. J. Anim. Sci. 83:2611-2617.

Shen, Q. W., M. J. Zhu, J. Tong, J. Ren and M. Du. 2007. $\mathrm{Ca} 2+/$ calmodulin-dependent protein kinase kinase is involved in AMP-activated protein kinase activation by alpha-lipoic acid in $\mathrm{C} 2 \mathrm{C} 12$ myotubes. Am. J. Physiol. Cell Physiol. 293:C1395-C1403.

Streeper, R. S., E. J. Henriksen, S. Jacob, J. Y. Hokama, D. L. Fogt and H. J. Tritschler. 1997. Differential effects of lipoic acid stereoisomers on glucose metabolism in insulin-resistant skeletal muscle. Am. J. Physiol. 273:E185-191.

Torrescano, G., E. A. Sánchez, B. Giménez, P. Roncalés and J. A. Beltrán. 2003. Shear values of raw samples of 14 bovine muscles and their relation to muscle collagen characteristics. Meat Sci. 64:85-91.

Wilkins, L. J., S. N. Brown, A. J. Phillips and P. D.Warriss. 2000. Variation in the colour of broiler breast fillets in the UK. Br. Poult. Sci. 41:308-312.

Woelfel, R. L., C. M. Owens, E. M. Hirschler, R. MartinezDawson and A. R. Sams. 2002. The characterization and incidence of pale, soft, exudative broiler meat in a commercial plant. Poult. Sci. 81:579-584.

Zerehdaran, S., A. L. Vereijken, J. A. van Arendonk and E. H. van der Waaijt. 2004. Estimation of genetic parameters for fat deposition and carcass traits in broilers. Poult. Sci. 83:521-525.

Zhang, Y., K. Hongtrakul, Q. G. Ma, L. T. Liu and X. X. Hu. 2009. Effects of dietary alpha-lipoic acid on anti-oxidative ability and meat quality in Arbor Acres broilers. Asian-Aust. J. Anim. Sci. 22:1195-1201. 